\title{
WIBAWA NEGARA KESATUAN R. I ATAS KEDAULATAN NEGARA WILAYAH UDARA
}

Oleh :

Nurlely Darwis, $\mathrm{SH}, \mathrm{MSi}^{1}$

(nulerly.darwis@gmail.com)

\begin{abstract}
Abstrak:
Negara kepulauan seperti Indonesia pada dasarnya memiliki kedaulatan yang penuh dan eksklusif terhadap perairan yang melingkupinya. Pelanggaran wilayah udara adalah suatu keadaan dimana pesawat terbang suatu negara sipil atau militer memasuki wilayah udara negara lain tanpa ijin sebelumnya dari negara yang dimasukinya. Dalam aturan Alur Laut Kepulan Indonesia/ALKI diantaranya menjelaskan bahwa setiap kapal dan pesawat (sipil dan militer) harus melakukan notifikasi terlebih dahulu, saat melintas ALKI. Kapal asing juga tidak boleh berhenti, berlabuh, atau mondarmandir, kecuali dalam keadaan musibah. Bila hal ini tidak dipenuhi maka jelas mereka melanggar aturan ALKI, yang merupakan salah satu wujud kedaulatan $R I$
\end{abstract}

\footnotetext{
${ }^{1}$ Mediator bersertifikat, Dosen Tetap Fakultas Hukum Universitas Suryadarama dan aktif sebagai anggota Majelis Pengawas Daerah Notaris Wilayah Jakarta Timur
} 


\section{PENDAHULUAN}

Peraturan Pemerintah Nomor 47 Tahun 1997 tentang Rencana Tata Ruang Wilayah Nasional pasal 1 ayat (5) disebutkan bahwa: "wilayah nasional adalah seluruh wilayah NKRI yang meliputi daratan, lautan dan udara". Pasal 1 angka 1 Undang-undang Nomor 43Tahun 2008 tentang Wilayah Negara mendefinisikan wilayah negara sebagai salah satu unsur negara yang merupakan satu kesatuan wilayah daratan, perairan pedalaman, perairan kepulauan dan laut teritorial beserta dasar laut dan tanah di bawahnya, serta ruang udara diatasnya, termasuk seluruh sumber kekayaan yang terkandung didalamnya.

Berdasarkan beberapa definisi diatas, dapat disimpulkan bahwa wilayah negara adalah tempat tinggal, tempat hidup dan sumber kehidupan warga negara yang meliputi daratan, lautan dan ruang udara, dimana suatu negara memiliki kedaulatan penuh atas wilayah negaranya. Dengan demikian dapat dikatakan bahwa wilayah (teritory) dari suatu negara itu terdiri dari tiga dimensi, yaitu wilayah daratan (land teritory), wilayah perairan (water teritory) dan wilayah udara (air teritory).

Sebagaimana diketahui bahwa ruang udara nasional adalah merupakan salah satu sumber daya alam yang terdapat diudara, dan sekaligus merupakan wilayah nasional sebagai wadah atau ruang/media, tempat Negara Kesatuan Republik Indonesia (NKRI) melaksanakan kedaulatan, hak berdaulat dan yurisdiksinya, sesuai dengan ketentuan dalam Konvensi Chicago 1944 tentang Penerbangan Sipil Internasional, dan juga dalam pasal 5 dan pasal 6 Undang-Undang Nomor 1 tahun 2009 tentang Penerbangan.

Bentuk penegakan kedaulatan atas wilayah ruang udara nasional, antara lain penegakan hukum terhadap pelanggaran wilayah udara kedaulatan RI, dan pelanggaran terhadap kawasan udara terlarang, baik kawasan udara Nasional maupun Asing, sesuai dengan Peraturan
Pemerintah RI Nomor 3 Tahun 2001 (PP No 3 tahun 2001) tentang Keamanan dan Keselamatan Penerbangan. Kawasan udara terlarang terdiri atas kawasan udara terlarang yang larangannya bersifat tetap (Prohibited Area) dan kawasan udara bersifat terbatas. Selain itu, terdapat pula pelarangan lain, yaitu perekaman dari udara menggunakan pesawat udara untuk kepentingan pertahanan dan keamanan negara.

Kewenangan Negara menetapkan batas negara, wilayah dapat diartikan sebagai ruang dimana manusia yang menjadi warga negara atau penduduk negara yang bersangkutan hidup serta menjalankan segala aktifitasnya. Didalam kondisi dunia yang sekarang ini, memungkinkan sebuah wilayah negara berbatasan dengan wilayah negara lainnya, dan didalamnya akan banyak terkait aspek yang saling mempengaruhi situasi dan kondisi perbatasan yang bersangkutan. Perbatasan negara seringkali didefinisikan sebagai garis imajiner diatas permukaan bumi yang memisahkan wilayah satu negara dengan wilayah negara lainnya. Sejauh perbatasan itu diakui secara tegas dengan traktat atau diakui secara umum tanpa pernyataan tegas, maka perbatasan merupakan bagian dari suatu hak negara terhadap wilayah. Atas dasar itu pula, maka setiap negara berwenang untuk menetapkan batas terluar wilayahnya.

Pemerintah Indonesia sampai dengan saat ini masih intens menyelesaikan penataan batas wilayah NKRI, termasuk di dalamnya adalah melakukan berbagai perundingan dengan negara tetangga untuk menentukan batas wilayah di segment-segment yang belum diperjanjikan. Hal ini merupakan bagian dari kewenangan dan kewajiban Pemerintah terhadap wilayahnya.

Berdasarkan PP. No 3 Tahun 2001 tentang Keamanan Dan Keselamatan Penerbangan, pemerintah mempunyai wewenang dan tanggung jawab mengenai pengaturan ruang udara untuk kepentingan 
pertahanan dan keamanan negara, guna memelihara kedaulatan negara atas wilayah udara nasional serta keselamatan penerbangan. Pasal 66 ayat (1) PP No. 3 Tahun 2001 disebutkan bahwa untuk menjamin keselamatan operasi penerbangan, ditetapkan Kawasan Udara Terlarang, Kawasan Udara Terbatas (Restricted Area) dan Kawasan Udara Berbahaya (Danger Area). Kawasan Udara Terlarang adalah ruang udara tertentu diatas daratan dan/atau perairan, dimana pesawat udara dilarang terbang melalui ruang udara tersebut karena pertimbangan pertahanan dan keamanan negara, serta keselamatan penerbangan.

Kawasan Udara Terbatas adalah ruang udara tertentu diatas daratan dan/atau perairan, karena pertimbangan pertahanan dan keamanan atau keselamatan penerbangan atau kepentingan umum, berlaku pembatasan penerbangan bagi pesawat udara yang melalui ruang udara tersebut. Sedangkan Kawasan Udara Berbahaya adalah ruang udara tertentu diatas daratan dan/atau perairan, yang sewaktu-waktu terjadi aktivitas yang membahayakan penerbangan pesawat udara. Pesawat udara Nasional maupun Asing dilarang terbang diatas daerah atau terbatas untuk menjamin keamanan nasional maupun keselamatan penerbangan. Larangan tersebut berlaku umum terhadap pesawat udara manapun juga, tanpa diskriminasi.

Penentuan daerah terlarang hanya atas pertimbangan keamanan nasional (nasional security), keselamatan penerbangan (aviation safety) maupun kemakmuran nasional (national prosperty), tidak boleh menentukan daerah terlarang atas pertimbangan politik suatu Negara. Bilamana pesawat udara asing ataupun nasional terlanjur berada didaerah terlarang, pesawat udara tersebut segera meninggalkan daerah terlarang. Tetapi jika mereka tidak menyadari posisinya, maka pesawat udara tersebut dikejar dan dipaksa untuk mendarat dibandar udara atau pangkalan udara yang berdekatan.
Terhadap pelanggaran wilayah udara Republik Indonesia dan atau kawasan udara terlarang oleh pesawat udara sipil, dilaksanakan penegakan hukum yang harus menjamin keselamatan dan keamanan awak pesawat, penumpang dan pesawat udara. Penegakan hukum terhadap pelanggaran wilayah udara dan atau kawasan udara terlarang sebagaimana dimaksud diatas, dilakukan oleh Tentara Nasional Indonesia.

Untuk penegakan kedaulatan dan hukum diruang Udara nasional, berdasarkan Aeronautical Information Publication (AIP) Indonesia, ditetapkan bahwa area yang menjadi area udara terlarang hanya WRP 23 Balikpapan Flare. Namun demikian, pada kenyataannya ruang udara nasional diatur oleh aturan-aturan internasional yang tidak sesuai dengan kehendak NKRI sebagai negara kepulauan (ArchipelagicState). Konvensi Perserikatan Bangsa-Bangsa/PBB tentang Hukum Laut Tahun 1982 pada pasal 53 mengatur bahwa negara kepulauan seperti Indonesia dapat menentukan alur laut dan rute penerbangan di atasnya.

Sementara itu, negara maju seperti Amerika Serikat pada kenyataannya belum meratifikasi Konvensi Hukum Laut Tahun 1982 (United Nations Convention On The Law of The Sea/UNCLOS 1982), padahal negara lain sudah banyak yang meratifikasi. Dengan demikian bila Amerika Serikat melintasi perairan dan wilayah udara nasional Indonesia, mereka masih berpedoman kepada aturan-aturan yang lama, seperti Traditional Route for Navigatio. Dilema bagi AS yang tidak pernah mengakui konvensi tersebut, kata Priyatna sebagai pakar Hukum Udara, bahwa AS tak pernah merasa tahu ada Konvensi Hukum Laut beserta ALKI. Dengan demikian dia akan merasa boleh melalui wilayah laut dan udara diatasnya tanpa perlu izin dari negara yang memiliki wilayah tersebut. Hal ini sering membuat terjadinya benturan dengan alasan bahwa Amerika Serikat belum meratifikasi UNCLOS 1982. 
Pasal 10 Undang-undang Nomor 34 Tahun 2004 tentang Tentara Nasional Indonesia/ TNI, Angkatan Udara bertugas antara lain: . Berdasarkan ketentuan tersebut diatas, TNI Angkatan Udara diberi wewenang dan tanggung jawab dalam penegakan kedaulatan dan hukum terhadap pelanggaran diwilayah udara, termasuk kawasan udara terlarang, terbatas dan daerah berbahaya sesuai dengan tugas pokoknya.

Untuk mengimplementasikan pelaksanaan tugas penegakan kedaulatan dan hukum diruang udara nasional tersebut, dibutuhkan peran Komando Pertahanan Udara Nasional (Kohanudnas). Karena Kohanudnas memiliki kemampuan deteksi, identifikasi dan penindakan terhadap seluruh wahana udara yang melakukan pelanggaran terhadap wilayah udara Republik Indonesia. Sementara itu, dalam melaksanakan tugas tersebut, Kohanudnas melaksanakan Operasi Pertahanan Udara, baik aktif maupun pasif. Hakekat Operasi Pertahanan Udara adalah merupakan kegiatan sebagai upaya mempertahankan kedaulatan wilayah nasional terhadap setiap ancaman yang menggunakan media udara.

\section{Legalitas Hukum Udara}

Sejarah Penerbangan dapat juga dilihat dari adanya pembentukan Undang Undang Republik Indonesia nomor 4 tahun 1976 tentang perubahan dan penambahan beberapa pasal dalam Kitab Undang-Undang Hukum Pidana / KUHP, bertalian dengan perluasan berlakunya ketentuan Perundang - undangan Pidana, Kejahatan Penerbangan, dan Kejahatan Terhadap Sarana / Prasarana Penerbangan.

Indonesia berkaitan dengan urusan penerbangan ternyata sudah diatur sejak jaman kompeni, dengan landasan hukum yang digunakan adalah Luchtvaart besluit 1932 (Staatsblad 1933 No. 118) dan
"Luchtvaart ordonnantic 1934" (Staatsblad 1934 No. 205 jo. Staatsblad 1942 No. 36). Selanjutnya Luchtvaart besluit 1932 dan Luchtvaart ordonnantic 1934 diganti dengan Undang-undang Nomor 83 Tahun 1958 tentang Penerbangan.

Dengan berjalannya waktu, pada tahun 1992 Undang-undang Nomor 83 Tahun 1958 diganti lagi dengan Undang-Undang Nomor 15 Tahun 1992 tentang Penerbangan. Pada tanggal 12 Januari 2009 Presiden Susilo Bambang Yudhoyono mensahkan Undang-Undang Nomor 1 Tahun 2009 tentang Penerbangan. Dibandingkan dengan undang-undang sebelumnya, Undangundang nomor 1 Tahun 2009 mengatur masalah penerbangan secara lebih detail. Sebagaimana dapat dibandingkan, Undang-undang Nomor 15 Tahun 1992 hanya terdiri dari 15 bab dan 76 pasal sedangkan Undang-undang Nomor 1 Tahun 2009 terdiri dari 24 bab dan 446 pasal. Dengan jumlah pasal yang lebih banyak, undang-undang yang baru tentunya meberikan kepastian hukum secara lebih baik bagi pemerintah, badan usaha, maupun setiap warga negara yang menggunakan jasa penerbangan.

\section{Kedaulatan Atas Wilayah Udara}

Negara terdiri dari beberapa unsur yaitu wilayah, penduduk, pemerintah, dan kedaulatan. Dalam ilmu Negara telah dijelaskan bahwa kedaulatan negara merupakan bagian dari kekuasaan Negara untuk memaksa semua penduduk agar mentaati Undang-undang dan peraturanperaturannya (kedaulatan kedalam-internal sovereignty). Disamping itu Negara mempertahankan kemerdekaannya terhadap serangan-serangan dari negara lain dan mempertahankan kedaulatan keluar (external sovereignty).

Masalah status hukum ruang udara diatas wilayah daratan dan perairan suatu negara berdaulat yang digunakan untuk 
melakukan penerbangan, mulai dibahas secara resmi dalam konferensi Paris 1910 yang berlatar belakang adanya kenyataan banyaknya penerbangan yang berlangsung di Eropa, tanpa memperhatikan kedaulatan negara dibawahnya, karena pada waktu itu belum ada pengaturannya, maka yang terjadi adalah kebebasan tinggal landas dari satu negara dan mendarat dinegara lain tanpa adanya ijin dari negara yang bersangkutan, apalagi pesawat udara dapat digunakan untuk mengangkut militer, mata-mata yang dapat mengancam keamanan nasional negara dibawahnya.

Deklarasi Djuanda yang dicetuskan pada Desember tahun1957 oleh Perdana Menteri Indonesia pada saat itu, Djuanda Kartawidjaja, adalah deklarasi yang menyatakan kepada dunia, bahwa laut Indonesia adalah termasuk laut sekitar, diantara dan didalam kepulauan Indonesia menjadi satu kesatuan wilayah NKRI, dan ini merupakan wilayah kedaulatan NKRI. Deklarasi Djuanda menyatakan bahwa Indonesia menganut prinsip-prinsip negara kepulauan (Archipelagic State) yang pada saat itu mendapat pertentangan besar dari beberapa negara, sehingga laut-laut antar pulau juga merupakan wilayah Republik Indonesia dan bukan kawasan bebas. Deklarasi Djuanda selanjutnya diresmikan menjadi Undang-undang No.4/PRP/1960 tentang Perairan Indonesia.

Setelah melalui perjuangan yang penjang, deklarasi ini pada tahun 1982 akhirnya dapat diterima dan ditetapkan dalam konvensi hukum laut PBB ke-III Tahun 1982 (United Nations Convention On The Law of The Sea/UNCLOS 1982). Selanjutnya delarasi ini dipertegas kembali dengan Undang-undang Nomor 17 Tahun 1985 tentang pengesahan UNCLOS 1982 bahwa Indonesia adalah negara kepulauan dan isi dari Deklarasi Juanda yang ditulis pada 13 Desember 1957, menyatakan:

- Bahwa Indonesia menyatakan sebagai negara kepulauan yang mempunyai corak tersendiri;
- Bahwa sejak dahulukala kepulauan nusantara ini sudah merupakan satu kesatuan;

- Ketentuan ordonansi 1939 tentang Ordonansi, dapat memecah belah keutuhan wilayah Indonesia dari deklarasi tersebut mengandung suatu tujuan :

- Untuk mewujudkan bentuk wilayah Kesatuan Republik Indonesia yang utuh dan bulat;

- Untuk menentukan batas-batas wilayah NKRI, sesuai dengan azas negara Kepulauan;

- Untuk mengatur lalu lintas damai pelayaran yang lebih menjamin keamanan dan keselamatan NKRI;

Secara umum teori kedaulatan udara "Negara Kolong" atas ruang udara atau angkasa diatas wilayah negara adalah bahwa kedaulatan negara diruang udara di atas wilayah teritorialnya bersifat utuh dan penuh. Ketentuan ini merupakan salah satu tiang pokok Hukum Internasional yang mengatur ruang udara. Hal ini dinyatakan dalam pasal 1 Konvensi Chikago 1944 tentang Penerbangan sipil internasional.

Bahwa sifat kedaulatan yang utuh dan penuh dari negara di ruang udara nasionalnya tersebut akan berbeda dengan sifat kedaulatan negara di laut wilayahnya, karena sifatnya yang demikian maka di ruang udara nasional tidak dikenal hak lintas demi pihak asing seperti terdapat di laut teritorial suatu negara. Dengan demikian sifat tertutup ruang udara nasional harus dapat dipahami demikian mengingat udara sebagai media gerak yang amat rawan ditinjau dari sudut pandang pertahanan keamanan negara kolong. Hal ini berarti pada dasarnya wilayah udara suatu negara adalah tertutup bagi pesawat-pesawat negara lain, yang artinya adalah bahwa kontrol atas wilayah udara hanya menjadi hak yang penuh dan utuh dari negara tersebut. 


\section{Fakta Pelanggaran Kedaulatan Di Wilayah Udara}

Beberapa contoh kasus ini merupakan bentuk pelanggaran wilayah kedaulatan udara Negara Kesatuan Republik Indonesia:

Paksa Mendarat Pesawat Asing, ini adalah bentuk keberhasilan TNI AU dalam hal mengawal Kedaulatan NKRI. Swa Bhuwana Paksa, atau sayap yang melindungi udara tanah air, Itulah semboyan TNI Angkatan Udara. Kini TNI AU kembali menunjukkan kewibawaanya pada pesawat asing yang melanggar kedaulatan udara RI. Dua pesawat tempur Sukhoi milik TNI memaksa sebuah pesawat asing mendarat di Manado, Sulawesi Utara. Pesawat asing itu dianggap melanggar batas wilayah udara nasional. Menurut informasi yang disampaikan Kepala Dinas Penerangan TNI AU/Kadispenau Marsma TNI Hadi Cahyanto, bahwa pesawat tempur dibawah kendali Komando sektor/Kosek Hanudnas 2 Makassar memaksa pesawat asing mendarat di Manado sekira pukul 10.29 WIB.

Pesawat asing itu bertipe Beechcraft 95 dengan callsign VH-RLS. Pesawat asing itu terbang dengan rute Darwin-Cebu namun melintasi wilayah udara Indonesia. Kejadian ini bukan pertama kalinya karena sebelumnya juga ada terjadi kasus yang hampir sama, dan yang menarik dalam hal ini adalah mayoritas pelanggar kedaulatan udara adalah negara Adikuasa AS.

Mencegat Pesawat Wakil PM Papua Nugini, sekitar November tahun 2011 lalu radar Komando Pertahanan Udara Nasional (Kohanudnas) mendeteksi ada pesawat asing melintas disekitar Balikpapapan. Dua pesawat Sukhoi TNI AU segera terbang memburu pelanggar tersebut, ternyata itu adalah sebuah pesawat P2-ANW Dassault Falcon 900EX bercat putih dengan logo merah yang terbang tanpa izin. Sukhoi segera melakukan tindakan terhadap pesawat tersebut. Ternyata dalam pesawat tersebut terdapat Wakil Perdana Menteri Papua Nugini Belden Namah. Pesawat tempur ini terus melakukan pengawalan terhadap tumpangan VIP tersebut selama 37 menit. Akhirnya atas kebijakan dan perintah Kohanudnas, pesawat dibiarkan aman demi pertimbangan politis antar NKRI dan Papua Nugini.

Sebuah pesawat komersil VH-PFK dipaksa mendarat di Pangkalan TNI Angkatan Udara Supadio, Pontianak, Kalimantan Barat, sekira pukul 11.00 WIB, Selasa (28/10/2014). Pesawat asal Singapura itu melintas tanpa izin diwilayah NKRI. Dua pesawat tempur milik Komando Pertahanan Udara Nasional (Kohnudnas) memaksa pesawat dengan tiga kru itu mendarat di Supadio. Ketiga kru langsung menjalani pemeriksaan di Markas TNI AU Pontianak . Komandan Pangkalan TNI AU Pontianak mengatakan pesawat melintasi udara NKRI tanpa izin, terbang dengan rute Sibu, Kuching, Malaysia menuju selatan Singapura. Untuk kedua kalinya dalam seminggu pesawat tempur Sukhoi TNI AU telah memaksa pesawat asing mendarat di Pontianak.

\section{(Metrotvnews.com,Pontianak 2014/10/28).}

Dua pesawat Sukhoi dari Makassar, Sulawesi Selatan, memaksa turun pesawat asal Arab Saudi di pangkalan angkatan udara El Tari Adi Sucipto, Kupang, Senin, 3 November 2014, sekitar pukul 14.40 Wita. Informasi yang dihimpun di Bandar Udara El Tari Kupang, diketahui pesawat asal Arab Saudi ini hendak menuju Australia dari Filipina dengan mengangkut 13 penumpang, termasuk enam orang kru dan pilot. Tujuh orang di antaranya warga negara Arab Saudi. Pesawat ini tidak disertai dokumen lengkap untuk masuk ke wilayah Indonesia. Pesawat ini dipaksa turun oleh dua pesawat Shukoi jenis SU30 dari Makassar yang melakukan pengejaran pesawat asal Arab Saudi itu. Pesawat asal Arab Saudi itu tiba di Bandara El Tari Kupang, pukul 14.40 Wita. Pesawat 
tersebut dipaksa turun, karena melintasi wilayah Indonesia tanpa izin. Dikabarkan, izin penerbangan pesawat Australia itu adalah Boeing, namun pesawat yang melintas berjenis Jet HZ 103. Pesawat tersebut sempat menginap dua malam di Singapura, sebelum melakukan penerbangan menuju Australia. Belum diketahui pasti misi pesawat tersebut ke Australia. (Senin, 3 November 2014 15:14 wib tempo.co, kupang)

\section{Kendala Prinsip Kedaulatan Atas Ruang Udara Nasional.}

Salah satu aspek yang perlu diperhatikan dalam pemanfaatan ruang udara beserta sumber daya didalamnya adalah masalah yurisdiksi. Prinsip-prinsip dalam yurisdiksi adalah prinsip teritorial, nasional, personalitas pasif, perlindungan atau keamanan, universalitas, dan kejahatan menurut kriteria hukum yang berlaku. Dalam hubungan dengan yurisdiksi negara diruang udara, sangat erat hubungannya dengan penegakkan hukum di ruang udara tersebut. Dengan adanya yurisdiksi, negara yang tersangkutan mempunyai wewenang dan tanggung jawab di udara untuk melaksanakan penegakkan hukum di ruang udara.

Sesuai Konvensi Chicago Tahun 1944, dalam Pasal 1 dinyatakan bahwa setiap negara mempunyai kedaulatan yang utuh dan penuh (complete and exclusive souvereignity) atas ruang udara atas wilayah kedaulatannya. Dari Pasal tersebut memberikan pandangan bahwa perwujudan dari kedaulatan yang penuh dan utuh atas ruang udara diatas wilayah teritorial, adalah:

Setiap negara berhak mengelola dan mengendalikan secara penuh dan utuh atas ruang udara nasionalnya;

Tidak satupun kegiatan atau usaha diruang udara nasional tanpa mendapatkan izin terlebih dahulu atau sebagaimana telah diatur dalam suatu perjanjian udara antara negara dengan negara lain baik secara bilateral maupun multilateral.

Sejak ditetapkannya konvensi tersebut sebagai hukum internasional dan telah diratifikasi oleh Pemerintah dengan Undang-undang Nomor 17 Tahun 1985, menyebabkan negara Indonesia sebagai negara kepulauan memiliki kewajiban menyediakan Alur Laut Kepulauan Indonesia ( ALKI) (archipelagic sea lane passages) yang merupakan jalur lintas damai bagi kapal-kapal asing. Hal tersebut juga berlaku pada wilayah udara diatas alur laut tersebut. Meskipun demikian, pemberlakuan ketentuan tersebut belum ada kesepakatan antara International Maritime Organization (IMO) dan International Civil Aviation Organization (ICAO), akibatnya belum ada ketentuan adanya pesawat udara yang mengikuti alur laut tersebut.

Undang-undang lain yang terkait dengan wilayah kedaulatan adalah Undangundang Nomor 5 Tahun 1983 tentang Zona Ekonomi Eksklusif Indonesia. Dalam undang-undang tersebut secara umum dinyatakan bahwa wilayah perairan Indonesia juga mencakup Zona Ekonomi Eksklusif (ZEE) yaitu jalur diluar dan berbatasan dengan laut wilayah sebagaimana ditetapkan dalam Undangundang Nomor 6 Tahun 1996 yang meliputi dasar laut, tanah dibawahnya dan air di atasnya dengan batas terluar 200 (dua ratus) mil laut diukur dari garis pangkal.

Dari uraian di atas, bahwa batas wilayah kedaulatan atas ruang udara nasional belum diatur dalam peraturan perundangundangan yang ada, bahwa undangundang hanya menetapkan bahwa Indonesia mempunyai wilayah kedaulatan atas ruang udara nasional sebagaimana ditetapkan dalam Pasal 5 dan Pasal 6 UU No. 1 Tahun 2009 tentang Penerbangan. Kegiatan penerbangan merupakan salah satu wujud kegiatan dan atau usaha terhadap wilayah kedaulatan atas wilayah udara yang diberi wewenang dan tanggung 
jawab kepada Pemerintah sebagaimana ditetapkan dalam Pasal tersebut bahwa dalam rangka penyelenggaraan kedaulatan negara atas wilayah udara Republik Indonesia Pemerintah melaksanakan wewenang dan tanggung jawab pengaturan ruang udara untuk kepentingan pertahanan dan keamanan negara, penerbangan dan ekonomi nasional.

\section{Wibawa TNI AU Dalam Penegakan Kedaulatan}

Sesuai dengan pasal 10 Undang-undang Nomor 34 Tahun 2004 tentang TNI, Angkatan Udara bertugas antara lain, melaksanakan tugas TNI matra udara di bidang pertahanan; menegakan hukum dan menjaga keamanan di wilayah udara Yurisdiksi Nasional sesuai dengan ketentuan hukum nasional dan hukum internasional yang telah diratifikasi; melaksanakan tugas TNI dalam pembangunan dan pengembangan kekuatan matra udara, dan melaksanakan pemberdayaan wilayah pertahanan udara.

Berdasarkan ketentuan tersebut di atas, TNI Angkatan Udara diberi wewenang dan tanggung jawab dalam penegakan kedaulatan dan hukum terhadap pelanggaran di wilayah udara, termasuk kawasan udara terlarang, terbatas dan daerah berbahaya sesuai dengan tugas pokoknya. Untuk mengimplementasikan pelaksanaan tugas penegakan kedaulatan dan hukum di ruang udara nasional tersebut, maka dibutuhkan peran Komando Pertahanan Udara Nasional (Kohanudnas). Karena Kohanudnas memiliki kemampuan deteksi, identifikasi dan penindakan terhadap seluruh wahana udara yang melakukan pelanggaran terhadap wilayah udara Republik Indonesia. Sementara itu, dalam melaksanakan tugas tersebut, Kohanudnas melaksanakan Operasi Pertahanan Udara, baik aktif maupun pasif.

Hakekat Operasi Pertahanan Udara adalah merupakan kegiatan sebagai upaya mempertahankan kedaulatan wilayah nasional terhadap setiap ancaman yang menggunakan media udara. Kegiatan tersebut pada dasarnya dilakukan secara terpadu yang melibatkan unsur-unsur TNI maupun Sipil yang mempunyai kemampuan pertahanan Udara/Hanud. Karena itu, wujud ancaman udara yang dapat muncul setiap saat mengharuskan Kohanudnas melaksanakan Operasi Pertahanan Udara secara terus menerus agar setiap ancaman yang menggunakan media udara dapat diteksi dan diantisipasi sedini mungkin. Adapun kegiatan Operasi Hanud dilaksanakan pada masa damai dan perang, dimana ancaman udara yang dihadapi akan berpengaruh terhadap penggunaan kekuatan dan pelaksanaan Kodal.

Pada dasarnya pelaksanaan Operasi Pertahanan Udara terbagi dalam Operasi Pertahanan Udara Aktif, yang meliputi kegiatan:

Deteksi: merupakan proses pengawasan terhadap sasaran udara secara elektronis maupun visual. Proses tersebut dimaksudkan untuk mengetahui secara pasti situasi udara yang terjadi pada saat itu. Dengan mengetahui data sasaran udara, dapat ditentukan lintasan, arah dan kecepatannya untuk selanjutnya dapat ditentukan sasaran tersebut merupakan ancaman udara atau bukan. Diteksi dapat dilaksanakan dengan cara elektronis dan visual.

Identifikasi, merupakan proses penentuan klasifikasi setiap sasaran udara kawan, sasaran udara tidak dikenal atau sasaran udara musuh. Dari hasil analisa data sasaran udara dapat ditentukan karakternya dan selanjutnya dapat ditentukan penggunaan Sistem Hanud yang tepat untuk mengatasi dan menanggulangi sasaran udara. Kegiatan identifikasi dapat dilakukan dengan cara elektronis, korelasi dan visual

Penindakan, merupakan tindak lanjut dari kegiatan identifikasi yang dilakukan oleh 
pesawat tempur sergap untuk membayangbayangi, menghalau, pemaksaan mendarat dan penghancuran. Selain itu, oleh rudal jarak sedang untuk penghancuran terhadap sasaran udara yang masuk daerah pertahanan rudal, dan Meriam Hanud/ Rudaltis untuk penghancuran terhadap setiap sasaran udara yang masuk daerah pertahanan.

Dengan demikian, Operasi Pertahanan Udara pada hakekatnya merupakan upaya untuk mempertahankan kedaulatan wilayah udara nasional terhadap setiap ancaman udara. Upaya tersebut dilakukan secara terpadu dengan melibatkan unsur TNI maupun Sipil yang berkemampuan Hanud dengan asas-asas operasi Hanud yang memiliki sasaran keunggulan udara dan tegaknya hukum di wilayah udara nasional. Namun demikian, pelaksanaan penegakan kedaulatan dan hukum di ruang udara nasional memiliki karakteristik khusus, sehingga dibutuhkan peralatan, baik berupa Alutsista dan sistem, maupun pengawakan sumber daya manusianya.

\section{Kesimpulan}

Selain wilayah darat dan laut, sebuah negara juga memiliki yurisdiksi wilayah udara sebagai klaim teritorial atas ruang udara diatasnya. Dalam hubungannya dengan ruang udara sebagai salah satu unsur wilayah dalam suatu negara, Pasal 1 Konvensi Paris 1919 menyatakan "Negara-negara pihak mengakui bahwa tiap-tiap negara mempunyai kedaulatan penuh dan eksklusif atas ruang udara yang terdapat diatas wilayahnya". Konvensi Chicago 1944 mengambil secara integral prinsip yang terdapat dalam Konvensi Paris 1919. Kedua konvensi tersebut dengan sengaja menjelaskan bahwa wilayah negara juga terdiri dari laut wilayahnya yang berdekatan.

Hal ini juga dinyatakan dalam pasal 2 Konvensi Jenewa mengenai laut wilayah dan oleh pasal 2 ayat (2) Konvensi PBB tentang Hukum Laut 1982 sebagaimana telah disinggung didepan. Ketentuanketentuan yang berlaku tentang navigasi udara, termasuk udara diatas laut wilayah, sama sekali berbeda dengan ketentuanketentuan yang mengatur pelayaran maritim. Terutama tidak ada normanorma hukum kebiasaan yang memperbolehkan secara bebas lintas terbang di atas wilayah negara, yang disamakan dengan prinsip hak lintas damai (right of passage innocent) di perairan nasional suatu negara.

Satu-satunya pengecualian adalah mengenai lintas udara diselat-selat internasional tertentu dan alur laut kepulauan. Sebagai akibatnya, kecuali kalau ada kesepakatan konvensional lain, suatu negara bebas untuk mengatur dan bahkan melarang pesawat asing terbang diatas wilayahnya dan tiap-tiap penerbangan yang tidak diizinkan merupakan pelanggaran terhadap kedaulatan teritorial negara yang berada dibawahnya.

Masalah pengawasan dan keamanan lalu lintas udara dan pengamanan atas pesawat-pewasat udara merupakan aspek sangat penting dalam pengaturan hukum yang dibuat oleh negara-negara. Selanjutnya untuk memperkuat ketentuanketentuan yang terdapat dalam konvensi, negara- $\neg$ negara sering membuat kesepakatan bilateral atau regional dibidang kerjasama pengawasan ataupun keamanan.

Masalah penetapan garis batas antara ruang udara dan ruang angkasa, adalah suatu kenyataan bahwa Negara-negara didunia ini mengakui perlu adanya penegasan mengenai perbatasan antara ruang udara yang berada dalam kedaulatan penuh suatu Negara dan ruang angkasa yang bebas dan hanya digunakan untuk kepentingan kemanusiaan dan perdamaian. Status hukum pesawat angkasa bolak-balik ini telah mulai dipersoalkan sejak tahun 1974, pada saat pembuatan konvensi tentang registrasi 
benda-benda yang diluncurkan ke ruang angkasa (registration convention 1974).

\begin{abstract}
Para ahli hukum pada umumnya berpendapat bahwa "space shuttle" mempunyai status hukum pesawat angkasa, bukan sebagai pesawat udara, karenanya tunduk pada ketentuanketentuan hukum angkasa dan tidak pada konvensi Chicago 1944 serta peraturanperaturan hukum udara lainnya. Teori ini lahir untuk memperkuat argumentasi klaim batas kedaulatan sebuah negara atas ruang udara sesuai dengan prinsip-prinsip hukum udara internasional. Namun teori ini juga dapat diterapkan untuk mengetahui batas ketinggian jelajah pesawat udara komersial. Sehingga apabila terjadi kecelakaan pesawat udara. dapat dipakai sebagai dasar argumentasi
\end{abstract}

Beragam kasus terkait keterbatasan TNI AU memantau penerbangan gelap dan menggunakan landasan udara diseluruh wilayah RI, kelemahan-kelemahan ATC Bandar udara dan ketiadaan integrasi kerja radar sipil dan militer dalam sistem Transmission Data Air Situation(TDAS) hingga strategi diplomasi internasional terkait pemanfaatan ruang udara dan antariksa RI hendaknya menjadi pelajaran untuk meningkatkan kapasitas pertahanan di wilayah perbatasan udara NKRI.

Pengelolaan dan pertahanan wilayah udara yang belum maksimal hendaknya juga menjadi prioritas proyeksi strategis kedepan terkait rencana pembangunan dan pemanfaatan sumber daya alam untuk kesejahteraan bangsa Indonesia. Diharapkan juga konsepsi pengelolaan dan pertahanan wilayah perbatasan udara merupakan konsepsi yang integral dengan penanganan wilayah perbatasan darat dan laut serta menjadi bagian dari agenda pembangunan lainnya seperti pengentasan wilayah tertinggal dan pemanfaatan sumber daya yang tersedia untuk pembangunan nasional. Tanpa kedua pandangan ini, maka cita-cita luhur untuk mengamankan dan mengelola seluruh wilayah perbatasan darat, laut dan udara hanya akan menjadi konsep dan segala upaya yang dilakukan berjalan di tempat.

\section{DAFTAR PUSTAKA}

Chainur Arrasjid, Pengantar Ilmu Hukum, Yani Corporation, Medan, 1988

Gunawi Kartasapoetra, Pokok-pokok Hukum Perburuhan, Cet I, Armico, Bandung, 1982. Harahap, M.Yahya, Hukum Acara Perdata Tentang Gugatan, Persidangan,Penyitaan Pembuktian dan Putusan Pengadilan, Sinar Grafika, Jakarta, 2005.

H.R. Abdussalam, Hukum Ketenagakerjaan (Hukum Perburuhan), Ed. Revisi, Restu Agung, Jakarta, 2009

Joseph. E Stiglitz, Making globalization work ( menyiasati globalisasi menuju dunia yang lebih adil ), Mizan, Jakarta, 2007.

Lalu Husni, Hukum Ketenagakerjaan Indonesia, Ed.Revisi, PT.Raja Grafindo Persada, Jakarta, 2007

Nasution, Bahder Johan, hukum Ketenagakerjaan, kebebasan berserikat bagi pekerja, Cv. Mandar Maju, Bandung, 2004. Philipus M Hadjon dan Tatiek Sri Djatmiati, Argumentasi Hukum, UGM Press, Surabaya, 2005.

Soepomo, Imam, Pengantar Hukum Perburuhan, Ed. Revisi, Djambatan, Jakarta, 2003.

Undang - Undang Republik Indonesia Nomor 39 Th 1999, tentang Pelanggaran Hak Asas Manusia, CV. Eko Jaya , Jakarta.

Undang-Undang Ketenagakerjaan, UU Republik Indonesia Nomor 13 Th 2003, cetakan II, November 2007, Penerbit Pustaka Pelajar 